\title{
Identification of Climatic and Soil Biocenotic Factors Influencing the Height Growth of Lapland Pine in North European Russia
}

\section{Elena Popova ( $\nabla$ en_popova@mail.ru )}

Institute of Geography https://orcid.org/0000-0002-2122-835X

\section{Anna E. Koukhta}

Institute of Geography RAS: FGBUN Institut geografii Rossijskoj akademii nauk

Igor O. Popov

Institute of global climate and ecology Roshydromet and RAS: Institut global'nogo klimata i ekologii Rosgidrometa i RAN

\section{Research}

Keywords: Lapland pine, height growth, climatic factors, biocenoses, soil, cluster analysis, Russia

Posted Date: February 19th, 2021

DOI: https://doi.org/10.21203/rs.3.rs-213344/v1

License: (c) (i) This work is licensed under a Creative Commons Attribution 4.0 International License. Read Full License 


\title{
IDENTIFICATION OF CLIMATIC AND SOIL BIOCENOTIC FACTORS INFLUENCING THE HEIGHT GROWTH OF LAPLAND PINE IN NORTH EUROPEAN RUSSIA
}

Elena N. Popova ${ }^{1 *}$, Anna E. Koukhta ${ }^{1,2}$, Igor O. Popov ${ }^{2}$

\begin{abstract}
Background: Lapland pine (Pinus sylvestris ssp. lapponica Fr. ex Hartm) is the geographical and climatic ecotype and subspecies of Scots pine. It is widespread in the north of Eurasia. Height growth is interconnected with both climatic parameters and the state of the habitat of pine trees.

Methods: Long-term data on height growth indices of Lapland pine (var. nana Pallas (1784)), growing in various humid biogeocenoses of three specially protected natural territories of the North European part of Russia were studied. Also sixteen basic climatic parameters averaged over the growth period of the examined trees were calculated for these regions. The comparison of the values of both different climatic parameters and the height growth of pine stands of various biogeocenoses was made by the method of cluster analysis.

Results: It was established that climatic parameters such as the mean daily average temperature in January and the amount of precipitation in the spring and early summer periods had a primary influence on the cluster similarity of the height growth of Lapland pine in the North European Russia. The proximity of soil and biocenotic conditions also influenced the similarity of height growth indices of Lapland pine, but had a lower rank within the two main clusters, distinguished by climatic values.
\end{abstract}

Conclusion: Our studies showed that it is possible to identify the rank influence of the most significant climatic factors and soil-biocenotic conditions on the height growth of the geographical ecotype Lapland pine subspecies with the cluster analysis.

Keywords: Lapland pine, height growth, climatic factors, biocenoses, soil, cluster analysis, Russia.

*Correspondence: en_popova@igras.ru

${ }^{1}$ Institute of Geography of the Russian Academy of Sciences, Staromonetniy pereulok, 29, Moscow, 119017, Russia

Full list of author information is available at the end of the article 


\section{Background}

Forest ecosystems play an important role in the life of our planet. They "provide ecological, economic, social and aesthetic services to natural systems and humankind, including refuges for biodiversity, provision of food, medicinal, and forest products, regulation of the hydrologic cycle, protection of soil resources, recreational uses, spiritual needs, and aesthetic values. Additionally, forests influence climate through exchanges of energy, water, carbon dioxide, and other chemical species with the atmosphere" (Bonan 2008). Wood species are closely related both to the climate of the regions in which they grow and to the soil that nourishes and saturates them with moisture through the root system (Rysin and Savelyeva 2008). In turn, the soil supporting the life of trees itself is formed under the influence of various climatic parameters, which are among the main soilforming factors. The vital activity of trees, therefore, depends both on macroecological conditions, which are determined by climatic factors of a vast geographical area, and on microecological - soilbiocenotic factors formed at a particular point in geographical space. The annual growth rate of pine trees is a function of weather conditions (temperature and humidity) both of the current year and several previous years. This dependence is especially evident in extreme conditions of pine growth, including sites at the northern border of its range (Elagin 1976; Rysin and Savelieva 2008).

The species Pinus sylvestris L. has a high degree of polymorphism, i.e. the presence of a wide variety of intraspecific forms, which are distinguished by the most diverse signs (Pravdin 1964). The largest taxonomic ranks within this species (subspecies) are distinguished on the basis of the geographical area of individual population growth. The main forest-forming species in the middle and most of the northern taiga of the North European territory of Russia is Lapland pine (Pinus sylvestris ssp. lapponica Fr. ex Hartm), one of the geographic subspecies of Pinus sylvestris L. (Pravdin 1964; GD 2020). Subspecies Lapland pine is widespread in Europe and Asia north of 61$62^{\circ} \mathrm{N}$. This is a low plant with a maximum height of $20 \mathrm{~m}$. There is also a wide variety of morphogenesis determined by the soil ecological conditions of growth, which already have lower taxonomic ranks and stand out at the species level of Pinus sylvestris L. within the main subspecies. In particular, the marsh edaphic ecotype of Scots pine, which grows in moist and waterlogged ecotopes, is var. nana Pallas (1784) (Pravdin 1964).

One of the main types of pine response to various environmental conditions is its linear growth (=height growth). Its variability is closely related to climatic factors and ecological conditions (Koukhta 2003, 2009; Chernogaeva and Kuhta 2018; Jansons et al. 2013a, b; Pozdnyakova et al. 2019; Zhou et al. 2019). The height growth of Scots pine in cold and moist regions has been limited by temperature in the previous summer and length of the growing period (McCarroll et al. 2003; Pensa et al. 2005; Salminen and Jalkanen 2005). Whereas height growth of pine in southern regions are restricted by amount of precipitation and available water, showing positive correlation with 
summer precipitation and negative correlation with summer temperature (Dobbertin et al. 2010; Mutke et al. 2003; Thabeet et al. 2009). Despite the importance of the linear growth indicators in studying various stands and their changes, interest to it among research communities is much lower than to the radial growth of trees (Jansons et al. 2013a; Sánchez-Salguero et al. 2015; van der Maaten et al. 2017; Misi et al. 2019). Identifying the effects of each of these factors is a difficult but important task for understanding the relationships in the "climate-soil-plant" system in various biogeocenoses. Most often, correlation and regression analyzes are used to identify the relationship between environmental factors and linear growth. Cluster analysis occupies a special place in multivariate statistical analysis, but it is practically not used in assessing the influence of ecological factors on plant trait changes. However, the advantage of the method is that it allows to compare qualitative and quantitative features and to build their classification systems (Gitis 2003).

The aim of this work is to assess the soil biocenotic and climatic characteristics of three different areas of Lapland pine growth, as well as to identify the relationships between individual soil and climatic parameters and the linear growth of this subspecies in the North European part of Russia with cluster analysis.

\section{Methods}

\section{Studied area description}

Studies were carried out in three specially protected natural territories (SPNTs) located in the North European part of Russia: the Kivach state nature reserve (SNR) (KNR 2020), the Polar Circle state nature complex reserve of regional significance (SNCR) (BCNKC 2020), and the Pechora-Ilych state nature biosphere reserve (SNBR) (PISNBR 2020) (Fig. 1). Accoding to climatic classification of B.P. Alisov (1956), the Polar Circle SNCR and the Kivach SNR are part of the northwestern subregion of the Atlantic-Arctic forest region of the temperate zone, and the Pechora-Ilych SNBR is located in the northeastern subregion of the Atlantic-Arctic forest region of the temperate zone, which differs from the northwestern by a greater continental climate (Fig. 1, Alisov 1956). The basis of the climatic zoning and allocation of climatic regions are the features of the radiation regime and atmospheric circulation. The climate of investigated regions is characterized as cold and quite humid.

According to the soil-geographical zoning, all studied SPNTs belong to the European-WestSiberian taiga-forest region of podzolic and sod-podzolic soils of the Boreal belt (Dobrovol'skii and Urusevskaya 2004). By floristic zoning, all the studied protected areas belong to the Holarctic kingdom, the Boreal kingdom, and are included in the Circumboreal or Euro-Siberian-Canadian floristic land areas (Voronov et al. 2002). 


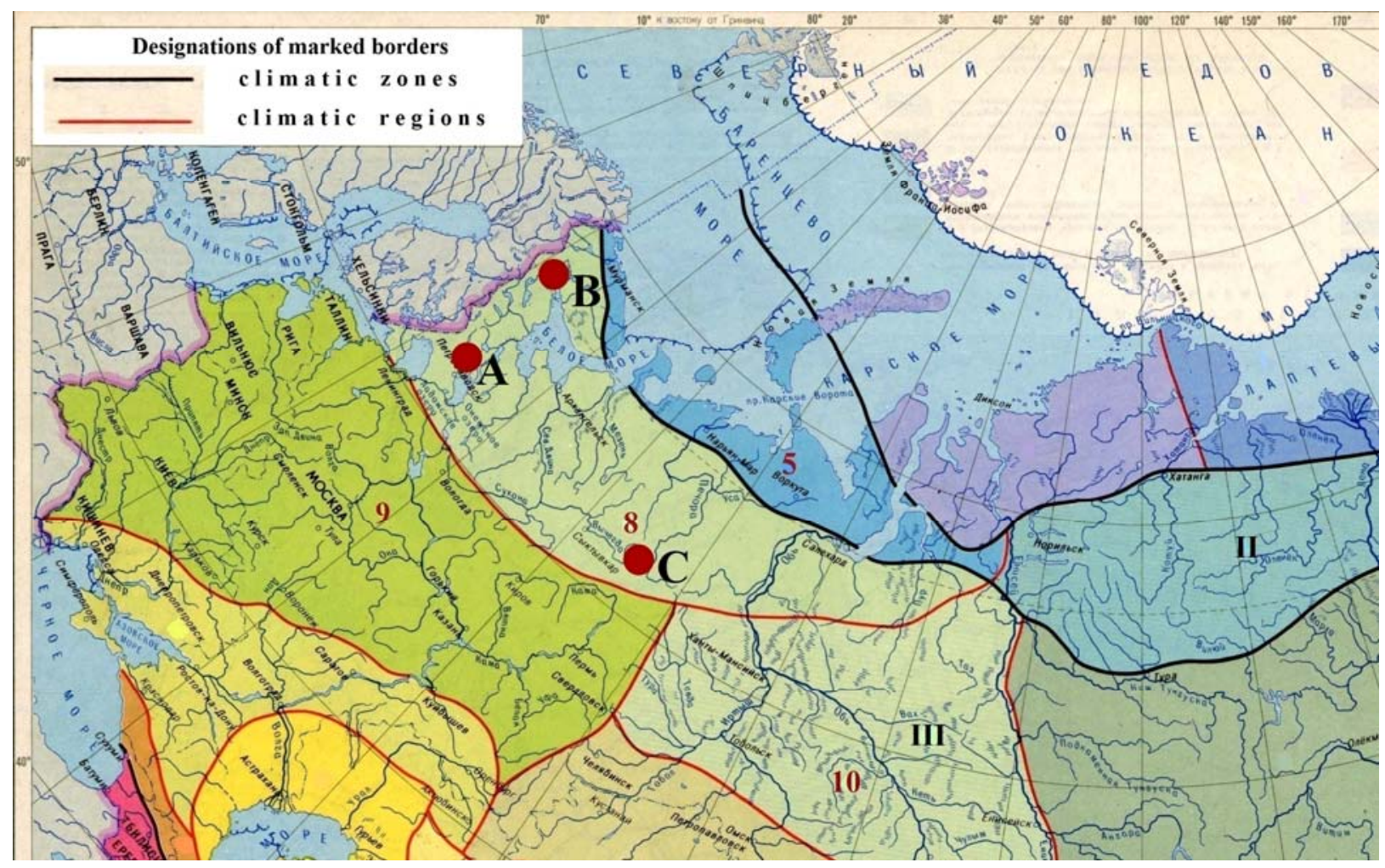

Fig. 1 Geographical location of study territories: A - Kivach SNR, B - Polar Circle SNCR, C - PechoraIlych SNBR. Climatic zones: II - Subarctic zone, III - Temperate zone. Climatic regions: 5 - Atlantic, 8 Atlantic-Arctic, 9 - Atlantic-Continental European, 10 - Continental West-Siberian. Borders of climatic zones and regions marked accoding to the classification of B.P. Alisov (1956) and specified accoding to data by N.A. Myachkova (MCZR 2020)

The Kivach SNR is located on the northwestern coast of Onega Lake in the southeastern region of the Baltic (Fennoscandinavian) crystalline shield. The territory of the reserve is characterized by a complex relief, formed as a result of tectonic and glacial activities. Ridge-hilly relief forms interspersed with lacustrine-glacial plains and swampy depressions (Fedorets et al. 2006). The variety of landforms determines the complexity of the soil cover. The territory is included in the Karelian province of alpha-humus podzols and bog soils of the subzone of podzolic soils of the middle taiga (Dobrovol'skii and Urusevskaya 2004). The most biocenoses of Kivach reserve are represented by different pine forests (Fedorets et al. 2006). The territory is located on the border of the ranges of subspecies of Pinus sylvestris L.: P. sylvestris ssp. sylvestris L. and P. sylvestris ssp. lapponica Fr. ex Hartm (Pravdin 1964). The investigated biocenoses of Lapland pine (dominant plant) and their soil types are:

A1 - dwaft shrubby sphagnum sedge pine forest; undergrowth - dwarf birch (Betula nana L.), sedge (Carex spp.), cassandra (Chamaedaphne calyculata (L.) Moench), Sphagnum spp., cranberry (Vaccinium oxycoccos L.), great bilberry (Vaccinium uliginosum L.), marsh trefoil (Menyanthes trifoliata L.); peat bog podzolic gleyed soil (PBPgS). 
A2 - dwaft shrubby sphagnum sereal pine forest; undergrowth - dwarf birch (Betula nana L.), sereals, cassandra (Chamaedaphne calyculata (L.) Moench), cranberry (Vaccinium oxycoccos L.), great bilberry (Vaccinium uliginosum L.); transitional peat bog soil (TPBS).

A3 - cotton grass sphagnum rosemary pine forest; undergrowth - dwarf birch (Betula nana L.), rosemary (Ledum palustre L.), bog rosemary (Andromeda polifolia L.), Sphagnum spp., cranberry (Vaccinium oxycoccos L.), cotton grass (Eriophorum vaginátum L.); transitional peat bog soil (TPBS).

A4 - cotton grass sphagnum dwaft shrubby pine forest; undergrowth - dwarf birch (Betula nana L.), sereals, Sphagnum spp., cassandra (Chamaedaphne calyculata (L.) Moench), cotton grass (Eriophorum vaginátum L.), cranberry (Vaccinium oxycoccos L.), great bilberry (Vaccinium uliginosum L.); transitional peat bog soil (TPBS).

A5 - rosemary sphagnum sedge pine forest; undergrowth - rosemary (Ledum palustre L.), cassandra (Chamaedaphne calyculata (L.) Moench), cotton grass (Eriophorum vaginátum L.), sedge (Carex spp.), Sphagnum spp., cloudberry (Rubus chamaemorus L.), cranberry (Vaccinium oxycoccos L.); humus peat bog gleyed soil ( $\mathrm{HPBgS})$.

A6 - dwaft shrubby sphagnum cereal pine forest; undergrowth - dwarf birch (Betula nana L.), sereals, Sphagnum spp., cassandra (Chamaedaphne calyculata (L.) Moench), cotton grass (Eriophorum vaginátum L.), cranberry (Vaccinium oxycoccos L.), great bilberry (Vaccinium uliginosum L.); humus peat bog gleyed soil ( $\mathrm{HPBgS})$.

A7 - rosemary sphagnum pine forest; undergrowth - rosemary (Ledum palustre L.), cassandra (Chamaedaphne calyculata (L.) Moench), cotton grass (Eriophorum vaginátum L.), cranberry (Vaccinium oxycoccos L.), cloudberry (Rubus chamaemorus L.); peat bog gleyed soil (PBgS).

A8 - dwaft shrubby sphagnum cereal pine forest; undergrowth - dwarf birch (Betula nana L.), sereals, Sphagnum spp., cassandra (Chamaedaphne calyculata (L.) Moench), cotton grass (Eriophorum vaginátum L.), cranberry (Vaccinium oxycoccos L.), great bilberry (Vaccinium uliginosum L.); humus peat bog gleyed soil (HPBgS).

A9 - rosemary sphagnum sedge pine forest; undergrowth - rosemary (Ledum palustre L.), cassandra (Chamaedaphne calyculata (L.) Moench), sedge (Carex spp.), Sphagnum spp., cranberry (Vaccinium oxycoccos L.); humus peat bog gleyed soil ( $\mathrm{HPBgS})$.

The Polar Circle SNCR is located in the Loukhsky municipal district in the northern part of the Republic of Karelia on the northwest coast of the White Sea in the Kandalaksha Bay coastal zone from the coastline to the border with the Murmansk region. In terms of soil and geographic zoning, the region belongs to the Kola-Karelian province of alpha-humus podzols and bog soils of the subzone of gley-podzolic soils and podzols of the northern taiga (Dobrovol'skii and Urusevskaya 2004). There are three main types of landscapes in the Polar Circle SNCR. The main part is 
occupied by the North-taiga East European lowland (57.6\%). Other types of landscapes are represented by various swamps (6.2\%) and marine areas (36.2\%) (SPTsR 2020). The studied biocenoses of Lapland pine (dominant plant) and their soil types are:

B1 - dwaft shrubby sphagnum green moss pine forest; undergrowth - alder (Alnus glutinosa (L.) Gaerth), dwarf birch (Betula nana L.), cowberry (Vaccinium vitis-idaea L.), great bilberry (Vaccinium uliginosum L.), Sphagnum spp., rosemary (Ledum palustre L.); peat bog podzolic soil (PBPS).

B2 - heather sphagnum dwaft shrubby pine forest; undergrowth - heather (Calluna vulgaris (L.) Hull), rosemary (Ledum palustre L.), dwarf birch (Betula nana L.), great bilberry (Vaccinium uliginosum L.), cloudberry (Rubus chamaemorus L.), Sphagnum spp.; humus peat bog gleyed soil ( $\mathrm{HPBgS})$.

B3 - heather sphagnum dwaft shrubby pine forest; undergrowth - dwarf birch (Betula nana L.), heather (Calluna vulgaris (L.) Hull), willow (Salix spp.), Sphagnum spp., cereals, great bilberry (Vaccinium uliginosum L.), cowberry (Vaccinium vitis-idaea L.), crowberry (Empetrum nigrum L.); humus peat bog gleyed soil (HPBgS).

The Pechora-Ilych SNBR is located in the Komi Republic on the western slope of the Ural Mountains. Currently, it exists in the form of two isolated sections located in the southwestern and eastern parts of the interfluve of the Upper Pechora and Ilych rivers. The studies were carried out on the Yakshinsky (southwestern) site, the boundary of which is formed by a segment of the river Pechora between the mouths of its right bank and left bank tributaries of Polovinnaya and Krutaya. The reserve is part of the Onego-Vychegodskaya province of podzolic and bog-podzolic soils of the subzone of podzolic soils of the middle taiga (Dobrovol'skii and Urusevskaya 2004). The most parts of the reserve are occupied by coniferous forests. There are raised and transitional sphagnum bogs in the depressions (Degteva and Lapteva 2013). The dominant tree is Pinus sylvestris L. As well as the Kivach reserve, the Pechora-Ilych SNBR is located on the southern border of the Lapland pine range and the northern border of Scots pine (Pravdin 1964). The studied biocenoses of Lapland pine (dominant plant) and their soil types are:

C1 - sphagnum rosemary pine forest; undergrowth - rosemary (Ledum palustre L.), Sphagnum spp., great bilberry (Vaccinium uliginosum L.), cowberry (Vaccinium vitis-idaea L.); raised peat bog soil (RPBS).

C2 - sphagnum rosemary pine forest; undergrowth - rosemary (Ledum palustre L.), Sphagnum spp., cranberry (Vaccinium oxycoccos L.); raised peat bog soil (RPBS).

C3 - rosemary green moss pine forest; undergrowth - Pinus sibirica Du Tour, rosemary (Ledum palustre L.), cranberry (Vaccinium oxycoccos L.), cowberry (Vaccinium vitis-idaea L.) 
green mosses (Pleurozium schreberi, Dicranum polysetum, Polytrichum piliferum); illuvial ferruginous gleyed podzol (IFgP).

C4 - rosemary green moss pine forest; undergrowth - Betula pubescens Ehrh., Picea obovata Ledeb., rosemary (Ledum palustre L.), great bilberry (Vaccinium uliginosum L.), blueberry (Vaccinium myrtillus L.), Sphagnum spp.; illuvial ferruginous gleyed podzol (IFgP).

C5 - sphagnum rosemary pine forest; undergrowth - rosemary (Ledum palustre L.), great bilberry (Vaccinium uliginosum L.), cranberry (Vaccinium oxycoccos L.), Sphagnum spp.; transitional peat bog soil (TPBS).

C6 - rosemary green moss pine forest; undergrowth - Picea obovata Ledeb., Betula pubescens Ehrh., rosemary (Ledum palustre L.), great bilberry (Vaccinium uliginosum L.), cowberry (Vaccinium vitis-idaea L.), green mosses (Pleurozium schreberi, Dicranum polysetum, Polytrichum piliferum), Sphagnum spp.; peat bog podzolic soil (PBPS).

C7 - rosemary green moss pine forest; undergrowth - rosemary (Ledum palustre L.), blueberry (Vaccinium myrtillus L.), great bilberry (Vaccinium uliginosum L.), cowberry (Vaccinium vitisidaea L.), green mosses (Pleurozium schreberi, Dicranum polysetum, Polytrichum piliferum), Sphagnum spp.; peat bog podzolic soil (PBPS).

\section{Stand data}

We investigated the annual variability of the indexed linear growth of Lapland pine growing in humid ecotopes, which were distinguished according to the classical typology of V.N. Sukachev (Sukachev 1972). Types of pine biocenoses were determined based on the work (Rysin and Savelieva 2008). The determination of soils for each examined area was carried out using the following works (Egorov et al. 1977; Degteva and Lapteva 2013; Fedorets et al. 2006). The ecotype of pine served as the object of our research is Pinus sylvestris ssp. lapponica Fr. ex Hartm var. nana Pallas (1784). It is representated at the fig. 2. 


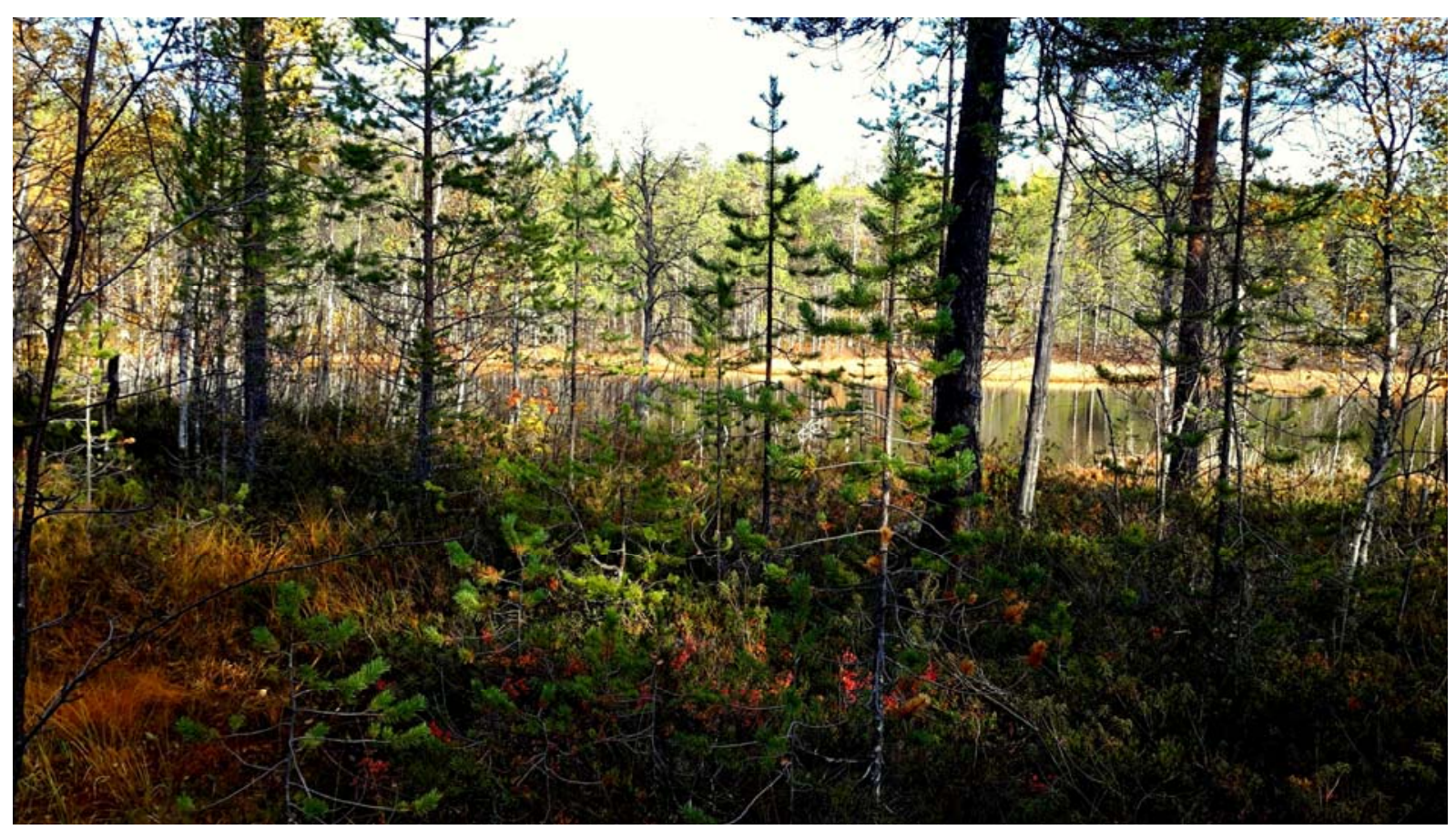

Fig. 2 The marsh edaphic ecotype of Lapland pine (Pinus sylvestris ssp. lapponica Fr. ex Hartm var. nana Pallas (1784)) in typical observed humid ecotope, the Polar Circle SNCR

The studies were multi-year and lasted from 2000 to 2013. The objects of measurement were undergrowth, young stand and maturing trees of Lapland pine. For unification, trees with similar morphological and age characteristics were selected. The height of the measured trees was not less than $1 \mathrm{~m}$ and not more than $2.5 \mathrm{~m}$. The age of registered undergrowth and maturing trees was 7-25 years. Stem internodes were measured on each tree, starting from the top (current year growth) and to the last clearly distinguishable one at the butt. The variability of the series of growths was estimated by the values of standard deviations. The series of growths were indexed by the standard method adopted in dendrochronology by dividing the absolute values of the each year growth by a moving average of 5 years. A similar procedure is used to remove the age trend and obtain annual deviations from the course of growth. Then, the values thus obtained were averaged over the trial plots. The calculation technique is described in (Koukhta 2009; Koukhta and Titkina 2005; Koukhta and Rumyantsev 2010).

\section{Climatic data}

For all three areas of the study we also calculated 16 climatic parameters that could affect the linear growth of Lapland pine. The calculations were carried out on the basis of daily resolution meteorological data obtained from ground-based measurements of air temperature and precipitations by a network of hydrometeorological stations of the international exchange of Roshydromet, which are located in the areas of research. These meteorological data are posted on the Internet at the site of the All Russian Scientific Research Institute of Hydrometeorological 
Information - World Data Center (RSRIHI-WDC 2014). The climatic values were average for the period 1991-2010, which coincides with the research period and the previous growing time of the examined trees. The calculated climatic parameters are:

Total annual precipitation (TAP): sum of precipitation for the year, mm;

Precipitation in spring (PSp): sum of precipitation for the spring period from March to May, $\mathrm{mm}$;

Precipitation in April-June (PAJn): sum of precipitation for the late spring - early summer period from April to June, mm;

Precipitation in July-September (PJIS): sum of precipitation for the late summer - early fall period from July to September, mm;

Precipitation in cold season (PCS): sum of precipitation for the cold season from October to April, mm;

Precipitation in growing season (PGS): sum of precipitation for the growing season from May to September, mm;

Mean annual air temperature (MAAT): mean annual average daily air temperature, ${ }^{\circ} \mathrm{C}$;

Mean temperature in May (MTM): average daily temperature in May, ${ }^{\circ} \mathrm{C}$;

Mean temperature in the warmest month (MTWM): average daily temperature in July, ${ }^{\circ} \mathrm{C}$;

Mean temperature in the coldest month (MTCM): average daily temperature in January, ${ }^{\circ} \mathrm{C}$;

Sum of active temperatures above $5^{\circ} \mathrm{C}\left(\mathrm{SAT}>5^{\circ} \mathrm{C}\right)$ : annual values of the sum of active average daily air temperatures above $5^{\circ} \mathrm{C}$, ${ }^{\circ} \mathrm{C} \times$ days (Popova et al. 2017);

Sum of active temperatures above $10^{\circ} \mathrm{C}\left(\mathrm{SAT}>10^{\circ} \mathrm{C}\right)$ : annual values of the sum of active average daily air temperatures above $10^{\circ} \mathrm{C},{ }^{\circ} \mathrm{C} \times$ days:

$$
T_{a}=\sum_{n=1}^{d} T_{n,>T 0}
$$

where $T_{a}$ is the annual sum of active temperatures (SAT), $T_{n}$ is the average daily air temperature above the temperature threshold $T_{0}$ which in this work is $10^{\circ} \mathrm{C}$ for a time period $d$ corresponding to the number of days in a year (Popova et al. 2017);

The number of days in a year with average daily temperature above $5^{\circ} \mathrm{C}\left(\mathrm{NDY}>5^{\circ} \mathrm{C}\right)$, days;

The number of days in a year with average daily temperature above $10^{\circ} \mathrm{C}\left(\mathrm{NDY}>10^{\circ} \mathrm{C}\right)$, days;

Hydrothermal coefficient (HTC) of Selyaninov:

$$
\mathrm{HTC}=r_{n} / 0.1 \Sigma T_{n}
$$

where $r_{n}$ is the daily precipitation sum in the growing season (PGS) of the calendar year $n ; \Sigma T_{n}$ is the sum of the average daily active air temperatures with a threshold of $10^{\circ} \mathrm{C}$ for the same period of the year (May-September) (Selyaninov 1928);

Simplified aridity index (SAI) of Budyko (Sirotenko and Pavlova 2012): 


$$
\mathrm{SAI}=0.18 \sum T_{>10^{\circ}} / r_{I-X I I}
$$

where $\sum T_{>10^{\circ}}$ is the annual sum of active air temperatures above $10^{\circ} \mathrm{C}\left(\mathrm{SAT}>10^{\circ} \mathrm{C}\right) ; r_{I-X I I}$ is the annual amount of precipitation (TAP).

\section{Statistical analyses}

Statistical processing was performed using the OpenOffice.org Calc table processor and the statistical computing environment R. Generalized data for the entire observation period for individual sites with increased moisture content ("humid biotopes" according to the Sukachev classification (1972)) in the three studied regions were compared using hierarchical cluster analysis with R function hclust (method "complete")) (Koukhta 2011).

Subsequently, based on the calculated climatic parameters for various protected areas, using the hierarchical cluster analysis, the similarity of their climatic conditions was evaluated. Cluster hierarchical analysis and dendrogram construction were performed using the SciPy package for the Python 3 programming language. The analysis was performed using the complete method of calculation of the distance between clusters (Raschka and Mirjalili 2017). The Euclidean distance was used as the metric. The Euclidean distance $(d)$ was calculated accoding Equation 4:

$$
d(p, q)=\left(\sum_{i=1}^{n}\left(p_{i}-q_{i}\right)^{2}\right)^{1 / 2}
$$

where $p$ and $q$ are the measured variables (i.e. values of climatic parameter of two compared plots); $i$ indicates the individual measurement value of the variable of a total number of $n$ measurements.

When clustering on several grounds, they were scaled using the min-max normalization method (Raschka and Mirjalili 2017).

\section{Results and discussion}

Cluster analysis of annual average values of linear growth indexes series variability of bog ecotype of Lapland pine in the humid habitats of the three examined SPNTs for the entire observation period revealed a separation of these indicators into two main similarity clusters (Fig. 3). One of them includes values obtained from various test sites of the Polar Circle SNCR and the Kivach SNR, belonging to the northwestern subregion of the Atlantic-Arctic forest region of the temperate zone, and the other includes values obtained from various test sites of Pechora-Ilych SNBR, which is part of the northeastern subregion of the Atlantic-Arctic forest region of the temperate zone. Thus, we see that the climatic conditions, in general, had a more significant effect on the clustering of the selected signs of linear growth. 


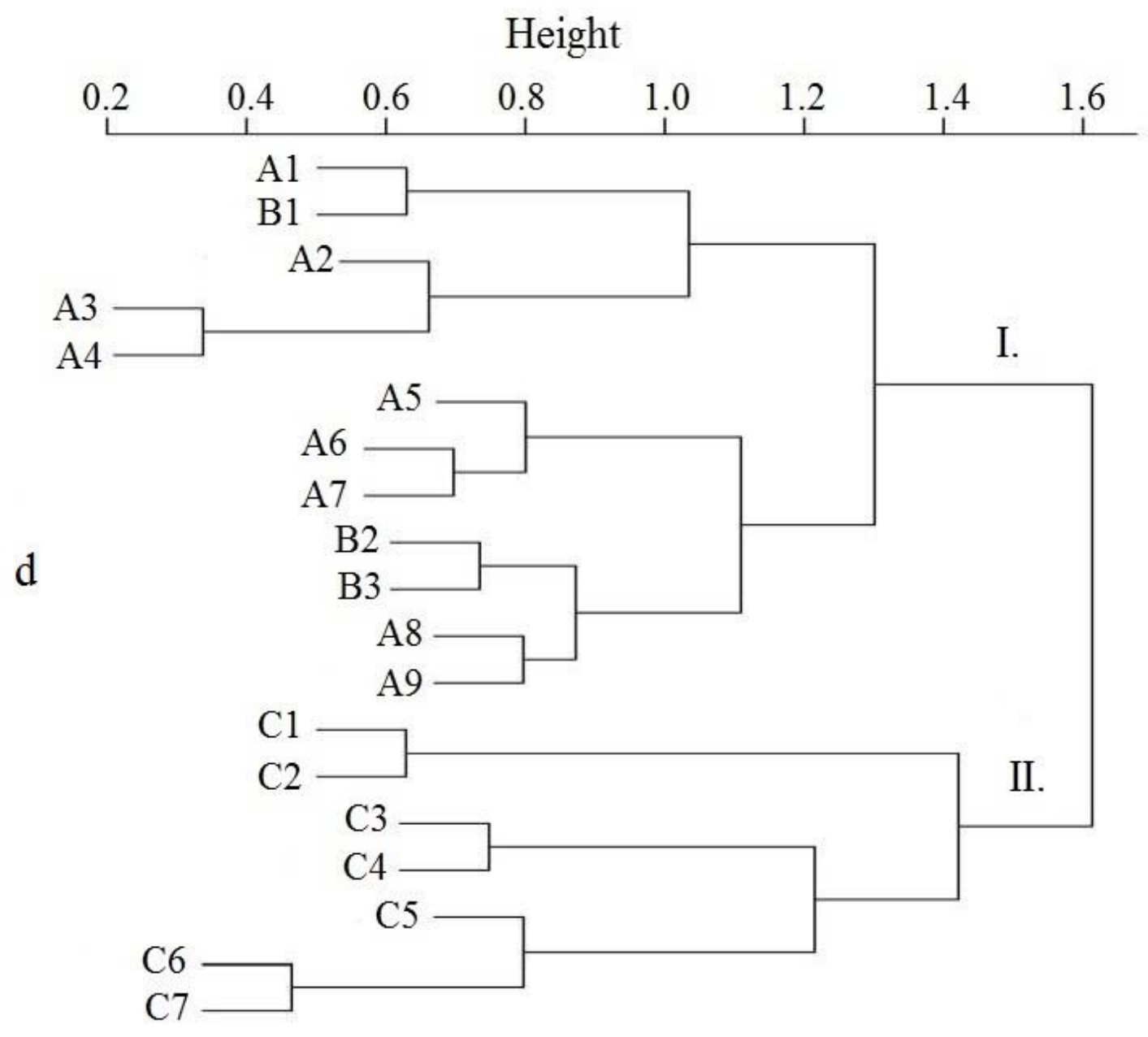

Fig. 3 Cluster analysis of height growth index indicators of Pinus sylvestris L. ssp. lapponica Fr. ex hartm. var. nana Pallas (1784) growing in various soil-biocenotic and climatic conditions of North European Russia ( $d$ is the Euclidean distance).

I. Northwest subregion of the Atlantic-Arctic forest region of the temperate zone. Republic of Karelia. Kivach SNR: A1 - PBPgS, A2 - TPBS, A3 - TPBS, A4 - TPBS, A5 - HPBgS, A6 - HPBgS, A7 - PBgS, A8 - HPBgS, A9 - HPBgS; Polar Circle SNCR: B1 -PBPS, B2 - HPBgS, B3 - HPBgS. II. The northeastern sub-region of the Atlantic-Arctic forest region of the temperate zone. Komi Republic. Pechora-llych SNBR: C1 - RPBS, C2 - RPBS, C3 - IFgP, C4 - IFgP, C5 - TPBS, C6 - PBPS, C7 PBPS. See a more detail description of the studied sites in "Methods: Studied area description"

Within these two main clusters, there is a similarity between the linear growth indices of the Lapland pine in test plots with similar soil and biocenotic conditions. So, the clusters of similarity of bog podzolic soils, raised peat bog soils, transitional peat bog soils and humus peat bog soils, illuvial ferruginous gleyed podzols are clearly distinguishable (Fig. 3). This indicates that the influence of the ecological niche, especially its edaphic component, also affects the linear growth of pine, but has a lower rank relative to the climatic effect.

The next stage of our research was the identification of those climatic parameters that influenced the separation of the values of the average annual variability of the indexed series of linear growth of the stands of Lapland pine into two different clusters. The calculated values of the 
selected climatic parameters averaged for the period 1991-2010 are given in Table 1. This period covers both the time of ground-based measurements of the linear growth of Lapland pine and the period of growth of this subspecies before the start of measurements, but subsequently taken into account when conducting field observations.

Table 1 The values of climatic parameters on the studied SPNTs, average for the period 1991-2010

\begin{tabular}{|c|c|c|c|}
\hline \multirow{2}{*}{$\begin{array}{l}\text { Climatic parametres } \\
\text { (CP) }\end{array}$} & \multicolumn{3}{|c|}{ Values of $\mathrm{CP}$ for observed regions } \\
\hline & Polar Circle SNCR & Kivach SNR & Pechora-Ilych SNBR \\
\hline TAP*, mm & 523.2 & 604.1 & 634.3 \\
\hline PSp, mm & 96.6 & 110.2 & 125.1 \\
\hline PAJn, mm & 125.0 & 137.1 & 151.8 \\
\hline PJlS, mm & 174.3 & 214.6 & 208.2 \\
\hline PGS, mm & 263.6 & 319.4 & 336.3 \\
\hline PCS, mm & 259.6 & 284.7 & 298.0 \\
\hline MAAT, ${ }^{\circ} \mathrm{C}$ & 0.97 & 2.98 & 0.54 \\
\hline $\mathrm{MTM},{ }^{\circ} \mathrm{C}$ & 4.4 & 7.9 & 8.1 \\
\hline $\mathrm{MTWM},{ }^{\circ} \mathrm{C}$ & 14.1 & 16.65 & 17.4 \\
\hline $\mathrm{MTCM},{ }^{\circ} \mathrm{C}$ & -10.4 & -9.4 & -16.1 \\
\hline $\mathrm{SAT}>5^{\circ} \mathrm{C},{ }^{\circ} \mathrm{C} \times$ days & 1443 & 1958 & 1890 \\
\hline $\mathrm{SAT}>10^{\circ} \mathrm{C},{ }^{\circ} \mathrm{C} \times$ days & 1050 & 1583 & 1517 \\
\hline $\mathrm{NDY}>5^{\circ} \mathrm{C}$, days & $132-133$ & 159 & $152-153$ \\
\hline $\mathrm{NDY}>10^{\circ} \mathrm{C}$, days & 80 & $109-110$ & 103 \\
\hline HTC & 2.5 & 2.0 & 2.2 \\
\hline SAI & 0.36 & 0.47 & 0.43 \\
\hline
\end{tabular}

* The description of climatic parameters is giving in the section "Climatic data".

After calculating the climatic parameters presented in table 1, we also performed a cluster analysis of similarities of the three studied SPNTs using both all values of climatic parameters and each separately (Fig. 4-6). 


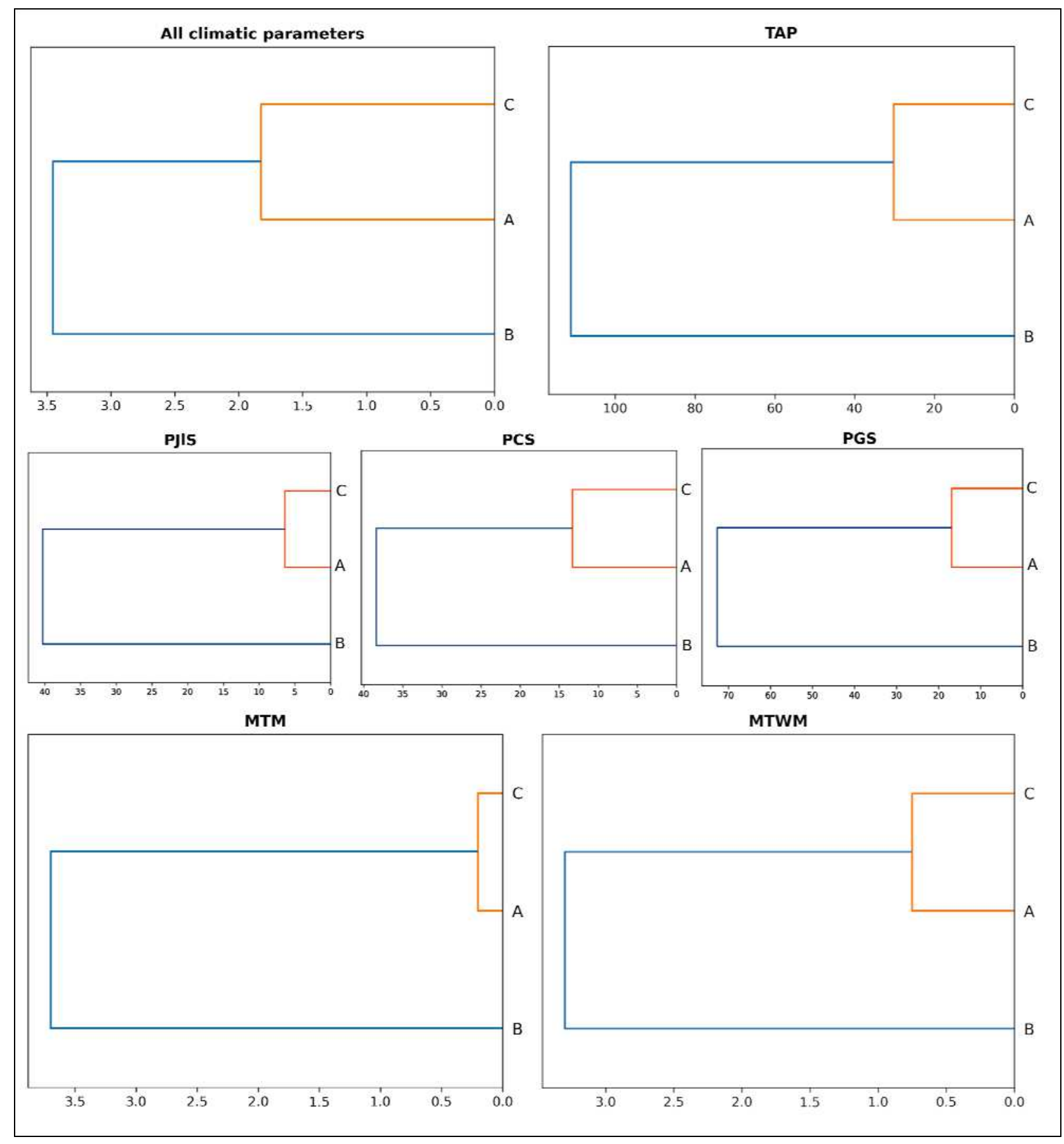

Fig. 4 Cluster analysis of the values of climatic parameters of the three SPNTs studied, averaged for the period 1991-2010 (All climatic parameters; TAP - total annual precipitation, mm; PJIS - precipitation in July-September, $\mathrm{mm}$; PCS - precipitation in cold season, $\mathrm{mm}$; PGS - precipitation in the growing season, $\mathrm{mm}$; MTM - mean temperature in May, ${ }^{\circ} \mathrm{C}$; MTWM - mean temperature in the warmest month (July), ${ }^{\circ} \mathrm{C}$ ). Studying sites: A - Kivach SNR, B - Polar Circle SNCR, C - Pechora-llych SNBR. The abscissa indicates the Euclidean distance 


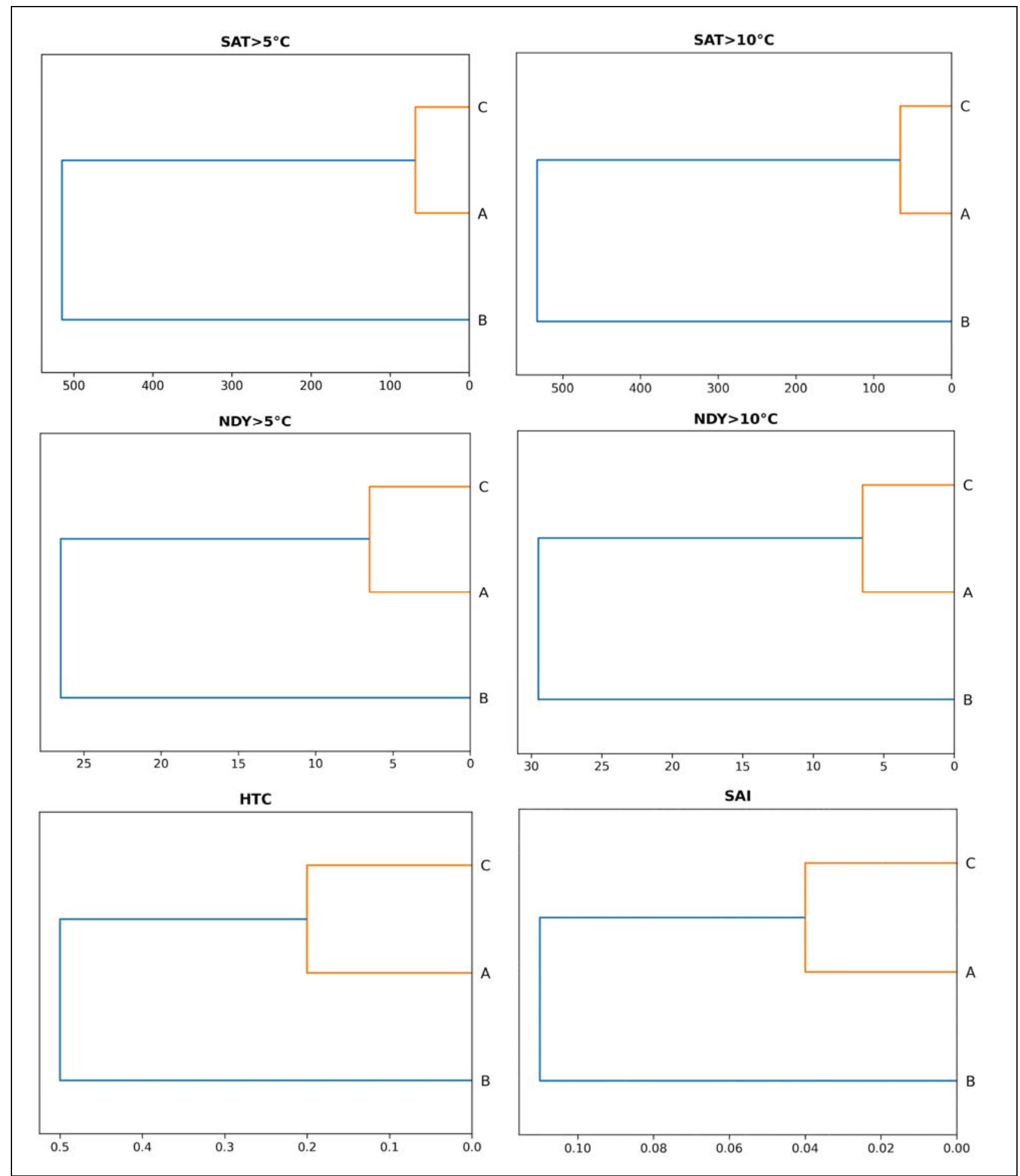

Fig. 5 Cluster analysis of the values of climatic parameters of the three SPNTs studied, averaged for the period $1991-2010\left(\mathrm{SAT}>5^{\circ} \mathrm{C}\right.$ - Sum of active temperature above $5^{\circ} \mathrm{C},{ }^{\circ} \mathrm{C} \times$ days; SAT $>10^{\circ} \mathrm{C}$ - Sum of active temperature above $10^{\circ} \mathrm{C},{ }^{\circ} \mathrm{C} x$ days; $\mathrm{NDY}>5^{\circ} \mathrm{C}$ - the number of days in a year with temperatures above $5^{\circ} \mathrm{C}$, days; $\mathrm{NDY}>10^{\circ} \mathrm{C}$ - the number of days in a year with temperatures above $10^{\circ} \mathrm{C}$, days; HTC - Selyaninov's Hydrothermal coefficient; SAI - Simplified aridity index). Studying sites: A - Kivach SNR, B - Polar Circle SNCR, C - Pechora-Ilych SNBR. The abscissa indicates the Euclidean distance

The results of clustering of all climatic parameters in general showed that the most similar across the entire set of values were the Kivach SNR and the Pechora-Ilych SNBR (Fig. 4). The same data were obtained for the much number of other climatic parameters (Fig 4 and 5). 
However, when conducting a cluster analysis by the climatic parameter mean annual air temperature (MAAT), the Polar Circle SNCR and the Pechora-Ilych SNBR turned out to be the closest (Fig. 6). This indicator brings the more northern (Polar Circle SNCR) and more continental (Pechora-Ilych SNBR) regions closer together.

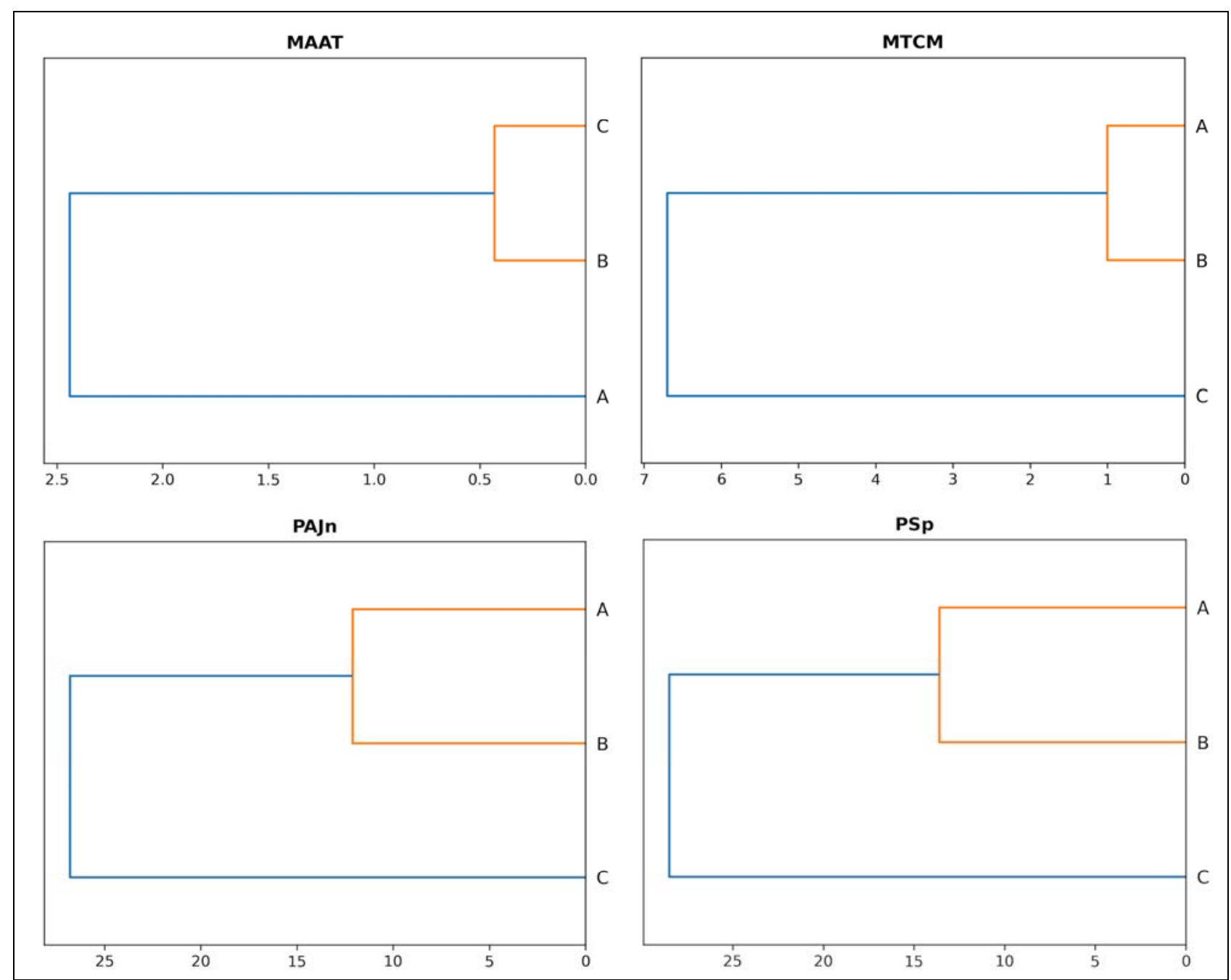

Fig. 6 Cluster analysis of the values of climatic parameters of the three SPNTs studied, averaged for the period 1991-2010 (MAAT - mean annual air temperature, ${ }^{\circ} \mathrm{C}$; MTCM - mean temperature in the coldest month (January), ${ }^{\circ} \mathrm{C}$; PSp - precipitation in spring, mm; PAJn - precipitation in April-June, mm). Studying sites: A - Kivach SNR, B - Polar Circle SNCR, C - Pechora-llych SNBR. The abscissa indicates the Euclidean distance

According to climatic values such as the mean average daily temperature of January (MTCM), the amount of precipitation in March-May (PSp) and precipitation in April-June (PAJn), the greatest similarities were found for the territories of the Kivach SNR and the Polar Circle SNCR (Fig. 6). It is for these surveyed SPNTs that the cluster analysis showed the greatest similarity in the values of the average annual variability of the height growth indexed series of Pinus sylvestris L. subsp. lapponica Fr. ex hartm. var. nana Pallas (Fig 3). Obviously, these climatic parameters have a decisive influence on the magnitude of the indexed height growth of the studied pine subspecies. Growth of pine in height occurs in spring and in the first half of summer. So, it is shown that in 
Karelia, in the middle taiga region, an intensive linear growth of pine trees begins in the first half of May and reaches a maximum in mid-June, completely stopping in August (Kishchenko 2019). The amount of precipitation in this period can have both a positive (in case of insufficient moisture) and a negative (in case of excessive moisture) effect on the linear growth of Scots pine (Koukhta 2009; Volkova et al. 2016; Pozdnyakova et al. 2019). Previously, significant negative correlation between the precipitation in May-Jule and height growth indices of Scots pine growing here were found for humid biotopes of the northern regions (Pozdnyakova et al. 2019). The same results (a negative correlation of the linear growth indices of Pinus sylvestris L. with the amount of precipitation in May and June) were obtained during examining the forest pine biotopes of the Baltic region with the cool humid Atlantic-Continental European climate (Janson et al. 2013b). The reason for this phenomenon is that in waterlogged biogeocenoses, an increased amount of precipitation causes water stress in pine trees and a decrease in the growth rate of internodes, and also contributes to a deterioration in the quality of established buds of renewal (Pozdnyakova et al. 2019).

The mean average daily January temperature is also of great importance for the vegetation of the northern regions as the temperature, as a rule, of the coldest month in harsh climate, therefore its effect on the height growth of the examined Lapland pine trees is understandable. The negative influence of the mean average daily January temperature on the growth of Scots pine was also noted in studies on the relationship between climatic factors and the height growth of pine stands of Siberia (Nikolaeva and Savchuk 2008; Shestakova et al. 2017) and the mountain regions of Spain (Sánchez-Salguero et al. 2015). However, for these regions (forest-steppe regions of Siberia and the Mediterranean climatic territories of Spain), a decrease in the height growth of the examined pines was also observed with an increase in the aridity of the growing season, and the correlation with precipitation was positive.

Depending on the growing conditions of the geographical ecotype of Scots pine, the set of climatic factors influencing its growth is different. In previous studies, using correlation analysis, it was found that the height growth of pine stands of the Penza region (Pinus sylvestris L. ssp. sylvestris L.) decreased with increasing temperature during the growing season and increased with an increase in the amount of precipitation in the current growing season (Koukhta and Titkina 2005; Volkova et al. 2016). When studying pine stands of the Mongolian pine (Pinus sylvestris L. ssp. mongolica Litv.) in the three northern regions of China, it was found that, as a rule, the height growth of pine trees increased with increasing average monthly temperature in May and the amount of precipitation from October to April, and decreased from increased precipitation in the previous growing season (Zhou et al. 2019). Also, a significant positive correlation of the height growth indices of Scots pine with May temperatures was noted by scientists conducting studies in Latvia (Janson et al. 2013b). According to our data, the May temperature did not have a significant effect 
on the cluster similarity of the indexed height growth of Lapland pine in the conditions of the northern Russian protected areas. The patterns obtained are consistent with the results of our previous studies, in which it was shown that the limiting factors in most habitats of boreal biogeocenoses of the north of the European territory of Russia are the lack or excess of precipitation, and not the temperature of the growing season (Chernogaeva and Kuhta 2018).

\title{
Conclusion
}

Our studies showed that cluster analysis can be used to identify the rank influence of climatic and soil-biocenotic conditions on the height growth of the Lapland pine subspecies. Also, with its help, it is possible to reveal the most significant climatic factors for a given geographical ecotype.

According to our results, the most significant impact on the annual variability of the height growth of Lapland pine was caused by precipitation in the spring and early summer, as well as the average daily mean temperature in January. A significant effect of the average January temperature on the height growth indicators of Lapland pine was revealed by us for the first time.

\begin{abstract}
Abbreviations
HPBgS: humus peat bog gleyed soil; HTC: hydrothermal coefficient; IFgP: illuvial ferruginous gleyed podzol; MAAT: mean annual air temperature; MTCM: mean temperature in the coldest month; MTM: mean temperature in May; MTWM: mean temperature in the warmest month; NDY: number of days in a year; PAJn: precipitation in April-June; PBgS: peat bog gleyed soil; PBPgS: peat bog podzolic gleyed soil; PBPS: peat bog podzolic soil; PCS: precipitation in cold season; PGS: precipitation in growing season; PJIS: precipitation in July-September; PSp: precipitation in spring; RPBS: raised peat bog soil; SAI: simplified aridity index; SAT: sum of active temperatures; SNBR: state nature biosphere reserve; SNCR: state nature complex reserve; SNR: state nature reserve; SPNTs: specially protected natural territories; TAP: total annual precipitation; TPBS: transitional peat bog soil.
\end{abstract}

\section{Acknowledgments}

The authors express their gratitude to the heads of the surveyed specially protected natural territories (Reserves) for their help and assistance in the fieldwork.

\section{Authors' contributions}

EP: literature review, goal and scope determination, method development, climatic data preparation, climatic indexes calculation, data processing and data analysis, table generation, map preparation, result interpretation, conclusion formulation, and manuscript drafting. AK: height growth pine data collection and preparation, height growth indexes calculation, photography, literature review, result interpretation, critical manuscript revision, and consulting. IP: data statistical processing, data cluster analysis, result and manuscript revision, map correction, literature review, and consulting. All authors read and approved the final manuscript.

\section{Funding}

The work was carried out in the framework of the theme of Fundamental scientific research of the Academy of Sciences No. 0148-2019-0009, AAAA-A19-119022190173-2: "Climate changes and their consequences for the environment and the livelihoods of the population in Russia"

\section{Availability of data and materials}

The datasets used in the current study are available from the corresponding author on reasonable request and after the conclusion of the agreement with the Institute of Geography of the Russian Academy of Sciences.

\section{Ethics approval and consent to participate}

Not applicable. 


\section{Consent for publication}

Not applicable.

\section{Competing interests}

The authors declare that they have no competing interests.

\section{Author details}

${ }^{1}$ Institute of Geography of the Russian Academy of Sciences, Staromonetniy pereulok, 29, Moscow, 119017, Russia. ${ }^{2}$ Yu.A. Izrael' Institute of Global Climate and Ecology, Glebovskaya str., 20b, Moscow, 107258, Russia.

\section{References}

Alisov BP (1956) Climate of the USSR. Publishing house of Moscow University, Moscow (in Russian)

BCNKC (2020) The Basin Council of North Karelian Coast. Non-Profit Corp. https://www.kareliacoast.org. Accessed 18 Mar 2020

Bonan GB (2008) Forests and climate change: Forcings, feedbacks, and the climate benefits of forests. Science 320(5882):1444-1449. https://doi.org/10.1126/science.1155121

Chernogaeva GM, Kuhta AE (2018) The Response of Boreal Forest Stands to Recent Climate Change in the North of the European Part of Russia. Russian Meteorology and Hydrology 43(6):418-424. https://doi.org/10.3103/S1068373918060109

Degteva SV, Lapteva EM (eds) (2013) Soils and soil cover of the Pechora-llych Reserve (Northern Urals). Syktyvkar ISBN:978-5-89606-513-5 (in Russian)

Dobbertin M, Eilmann B, Bleuler P, Giuggiola A, Graf-Pannatier E, Landolt W, Schleppi P, Rigling A (2010) Effect of irrigation on needle morphology, shoot and stem growth in a drought-exposed Pinus sylvestris forest. Tree Physiol. 30:346-360. http://doi.org/10.1093/treephys/tpp123

Dobrovol'skii GV, Urusevskaya IS (2004) Soil geography. Second Edition. Publishing house of Moscow University, Moscow ISBN:5-211-04481-9, KolosC, Moscow ISBN:5-9532-0254-7(in Russian)

Egorov VV, Fridland VM, Ivanova EN, Rozov NN, Nosin VA, Friev TA (1977) Classification and diagnostics of soils in the USSR. Kolos, Moscow (in Russian)

Elagin IN (1976) Seasonal development of pine forests. Nauka, Novosibirsk (in Russian)

Fedorets NG, Morozova RM, Bakhmet ON, Solodovnikov AN (2006) Soils and soil cover of the Kivach reserve. Proceedings of the Karelian Scientific Center of the Russian Academy of Sciences, Petrozavodsk 10:131-152 (in Russian)

Gitis L (2003) Statistical classification and cluster analysis. Publishing House of Moscow State Mining University, Moscow ISBN:5-7418-0010-6 (in Russian)

GD (2020) The Gymnosperm Database; https://www.plantarium.ru/page/view/item/28394.html. Accessed 15 Mar 2020

Jansons A, Matisons R, Baumanis I, Purina L (2013a) Effect of climatic factors on height increment of Scots pine in experimental plantation in Kalsnava, Latvia. Forest Ecology and Management 306:185-191. http://doi.org/10.1016/j.foreco.2013.06.039

Jansons A, Matisons R, Lībiete-Zālīte Z, Baders E, Rieksts-Riekstinëš R (2013b) Relationships of height growth of lodgepole pine (Pinus contorta var. latifolia) and Scots pine (Pinus sylvestris) with climatic factors in Zvirgzde, Latvia. Baltic Forestry 19(2):236-244.

Kishchenko IT (2019) Seasonal formation of aboveground phytomass of middle-aged pine stands of various types of forest in the middle taiga. Lesovedenie (Forestry) 1:19-28 (in Russian)

KNR (2020) Kivach Nature Reserve. https://zapkivach.ru. Accessed 20 Mar 2020

Koukhta AE (2003) Linear growth of trees as an indicator of the state of the environment. Siberian ecological journal 6:767-771 (in Russian)

Koukhta AE (2009) Influence of temperature and precipitation on the annual linear growth of Scots pine on the shores of the Kandalaksha Bay. Lesnoy Vestnik (Forestry bulletin) 1:61-67 (in Russian)

Koukhta AE (2011) Climatic and local factors of Scots pine growth parameter variability in three specially protected territories of the North of Russia. Lesnoy Vestnik (Forestry bulletin) 4:221-226 (in Russian)

Koukhta AE, Titkina SN (2005) Climatogenic variations in linear increment of Scots pine juvenile plants in model stands in the Penza region. Problems of ecological monitoring and modeling of ecosystems 20:251-261 (in Russian)

Koukhta AE, Rumyantsev DE (2010) Linear and radial increments of Scots pine in the Volga-Kama and Central-Forest state natural reserves. Lesnoy Vestnik (Forestry bulletin) 3:88-95 (in Russian)

McCarroll D, Jalkanen R, Hicks S, Tuovinen M, Gagen M, Pawellek F, Eckstein D, Schmitt U, Autio J, Heikkinen O (2003) Multiproxy dendroclimatology: a pilot study in northern Finland. Holocene 13:829838. https://doi.org/10.1191/0959683603hl668rp

MCZR (2020) Map of climatic zoning of Russia https://map-rus.com/klimat-district.html Accessed $10 \mathrm{Apr}$ 2020 
Misi D, Puchałka R, Pearson C, Robertson I, Koprowski M (2019) Differences in the Climate-Growth Relationship of Scots Pine: A Case Study from Poland and Hungary. Forests 243(10):1-12. https://doi.org/10.3390/f10030243

Mutke S, Gordo J, Climent J, Gil L (2003) Shoot growth and phenology modelling of grafted Stone pine (Pinus pinea L.) in Inner Spain. Ann. For. Sci. 60:527-537. https://doi.org/10.1051/forest:2003046

Nikolaeva SA, Savchuk DA (2008) Climatogenic response of pine trees in the south of the Tomsk region. J. of the Siberian Federal University, Biology 1(4):400-413 (in Russian)

Pensa M, Salminen H, Jalkanen R (2005) A 250-year-long height-increment chronology for Pinus sylvestris at the northern coniferous timberline: a novel tool for reconstructing past summer temperatures? Dendrochronologia 22:75-81. https://doi.org/10.1016/.j.dendro.2005.02.005

PISNBR (2020) Pechora-llych State Nature Biosphere Reserve. https://www.pechora-reserve.ru. Accessed 22 Mar 2020

Popova EN, Yasyukevich VV, Popov IO (2017) On the correct use of cumulative applied climate indices for studying biological objects. Russian Meteorology and Hydrology 42(10):661-664. https://doi.org/10.3103/S1068373917100053

Pozdnyakova EA, Volkova GL, Koukhta AE (2019) Variability of Scots pine linear increment in different types of biotopes of the European part of Russia. Lesnoy Vestnik (Forestry bulletin) 23(2):61-69. https://doi.org/10.18698/2542-1468-2019-2-61-69 (in Russian)

Pravdin LF (1964) Pinus sylvestris. Variability, intraspecific taxonomy and selection. Nauka, Moscow (in Russian)

Raschka S, Mirjalili V (2017) Python Machine Learning - Second Edition. Packt Publishing Ltd. ISBN:9781787125933

RSRIHI-WDC (2014) All Russian Research Institute of Hydrometeorological Information - World Data Center http://www.meteo.ru. Accessed 10 Feb 2014

Rysin LP, Savelyeva LI (2008) Pine forests of Russia. Partnership of scientific publications "KMK", Moscow ISBN:978-5-87317-512-3 (in Russian)

Salminen H, Jalkanen R (2005) Modelling the effect of temperature on height increment of Scots pine at high latitudes. Silva Fenn. 39:497-508

Sánchez-Salguero R, Camarero JJ, Hevia A, Madrigal-González J, Linares JC, Ballesteros-Canovas JA, Sánchez-Miranda A, Alfaro-Sánchez R (2015) What drives growth of Scots pine in continental Mediterranean climates: Drought, low temperatures or both? Agric. For. Meteorol. 206:151-162. https://doi.org/10.1016/j.agrformet.2015.03.004

Selyaninov GT (1928) On agricultural assessment of climate. Works on agricultural meteorology. Issue 20:169-178 (in Russian).

Shestakova TA, Voltas J, Saurer M, Siegwolf RTW, Kirdyanov AV (2017) Warming effects on Pinus sylvestris in the cold-dry Siberian forest-steppe: positive or negative balance of trade? Forests 8(12):121. https://doi.org/10.3390/f8120490

Sirotenko OD, Pavlova VN (2012) Methods for assessing the impact of climate change on agricultural productivity. In: Senenov SM, Popova EN, Trifonova-Yakovleva AM, Yasukevich VV (eds) Methods for assessment of climate change consequences for physical and biological systems, Roshydromet, Moscow, pp 165-189 ISBN:978-5-904206-10-9 (in Russian)

SPTsR (2020) Specially protected territories of Russia. http://oopt.aari.ru. Accessed 20 Aug 2020 (in Russian)

Sukachev VN (1972) Selected works in three volumes. In: Lavrenko EM (ed) Vol. 1: Fundamentals of forest typology and biogeocenology. Nauka, Leningrad (in Russian)

Thabeet A, Vennetier M, Gadbin-Henry C, Dendelle N, Roux M, Caraglio Y, Vila B (2009) Response of Pinus sylvestris L. to recent climatic events in the French Mediterranean region. Trees - Structure and Function 23:843-853. http://doi.org/10.1007/s00468-009-0326-z

van der Maaten E, Mehl A, Wilmking M, van der Maaten-Theunissen M (2017) Tapping the tree-ring archive for studying effects of resin extraction on the growth and climate sensitivity of Scots pine. Forest ecosystems 4:7. http://doi.org/10.1186/s40663-017-0096-9

Volkova GL, Pozdnyakova EA, Volkov AA, Koukhta AE (2016) Influence of climatic factors on Scots pine forestation and natural undergrowth in the Penza region. Fundamental and Applied Climatology, 2:107118. http://doi.org/10.21513/2410-8758-2016-2-107-118

Voronov AG, Drozdov NN, Krivolutsky DA, Myalo EG (2002) Biogeography with the basics of ecology. Publishing house of Moscow State University, Moscow ISBN:5-211-04664-1, Publishing house "Higher school", Moscow ISBN:5-06-004341-X (in Russian).

Zhou Y, Lei Z, Zhou F, Han Y, Yu D, Zhang Y (2019) Impact of climate factors on height growth of Pinus sylvestris var. mongolica // PloS ONE 14(3):e0213509. https://doi.org/10.1371/journal.pone.0213509 


\section{Figures}

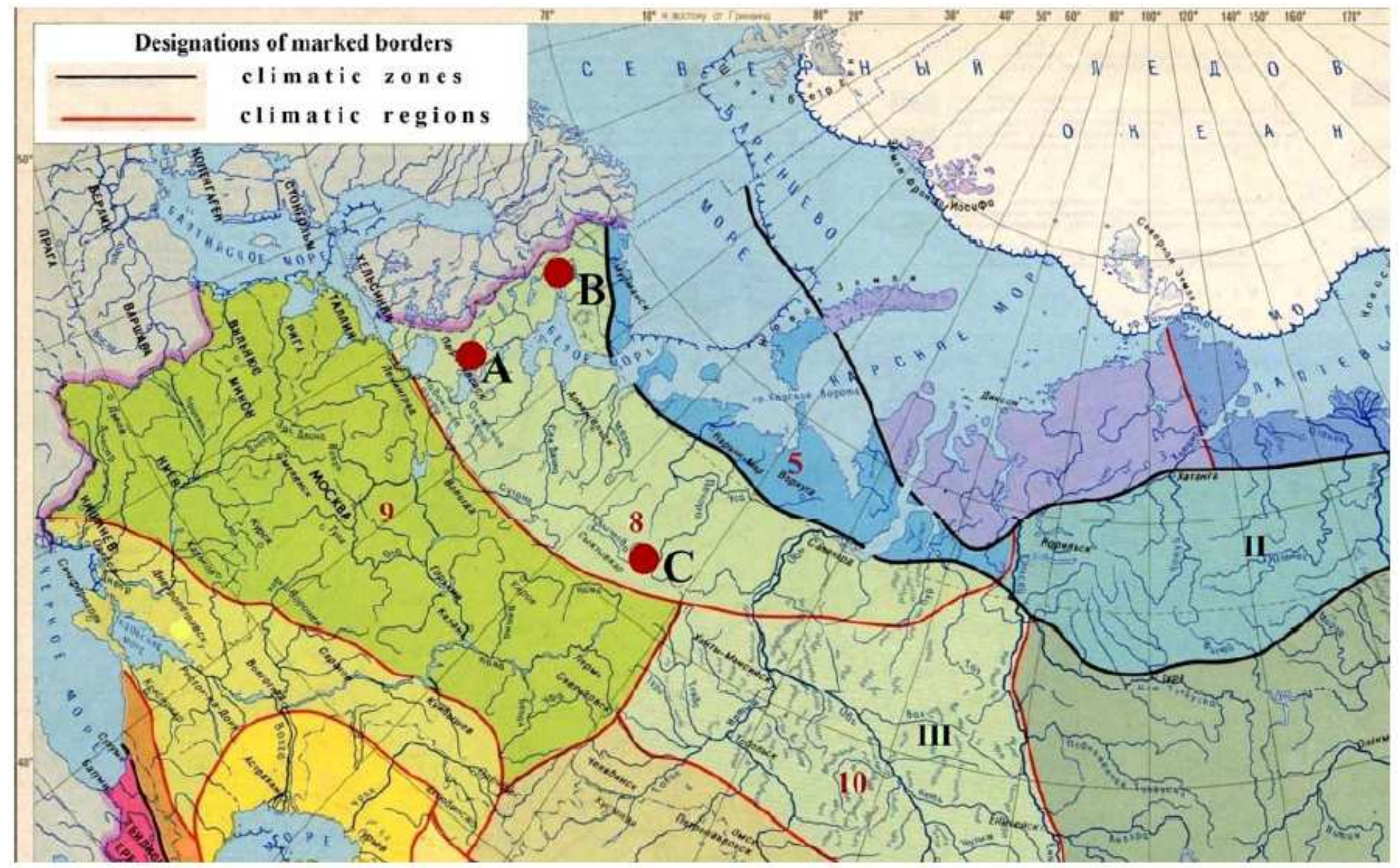

Figure 1

Geographical location of study territories: A - Kivach SNR, B - Polar Circle SNCR, C - Pechora- llych SNBR. Climatic zones: II - Subarctic zone, III - Temperate zone. Climatic regions: 5 - Atlantic, 8 - Atlantic-Arctic, 9 - Atlantic-Continental European, 10 - Continental West-Siberian. Borders of climatic zones and regions marked accoding to the classification of B.P. Alisov (1956) and specified accoding to data by N.A. Myachkova (MCZR 2020) Note: The designations employed and the presentation of the material on this map do not imply the expression of any opinion whatsoever on the part of Research Square concerning the legal status of any country, territory, city or area or of its authorities, or concerning the delimitation of its frontiers or boundaries. This map has been provided by the authors. 


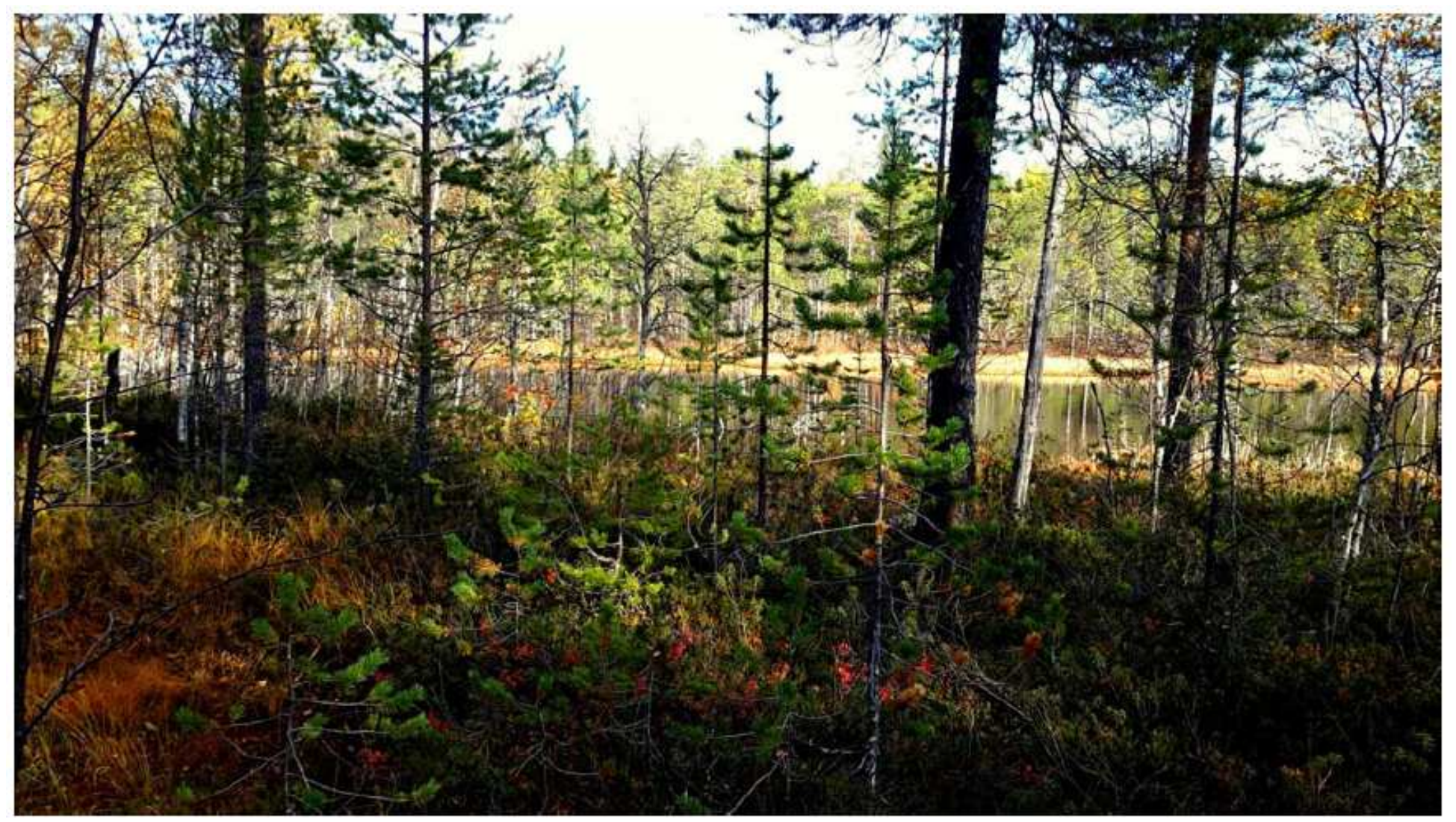

\section{Figure 2}

The marsh edaphic ecotype of Lapland pine (Pinus sylvestris ssp. lapponica Fr. ex Hartm var. nana Pallas (1784)) in typical observed humid ecotope, the Polar Circle SNCR 


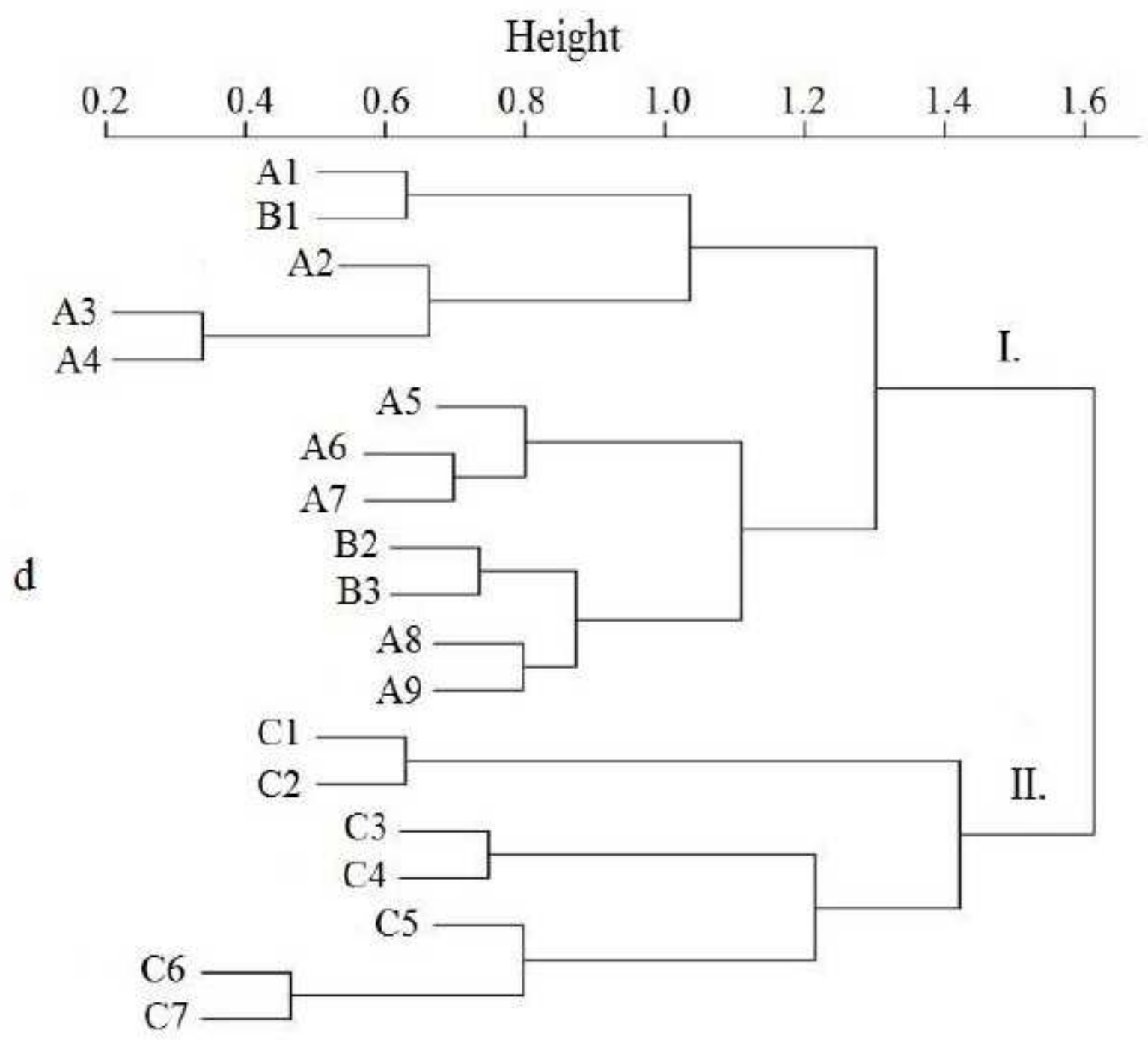

\section{Figure 3}

Cluster analysis of height growth index indicators of Pinus sylvestris L. ssp. lapponica Fr. ex hartm. var. nana Pallas (1784) growing in various soil-biocenotic and climatic conditions of North European Russia ( $d$ is the Euclidean distance). I. Northwest subregion of the Atlantic-Arctic forest region of the temperate zone. Republic of Karelia. Kivach SNR: A1 - PBPgS, A2 - TPBS, A3 - TPBS, A4 - TPBS, A5 - HPBgS, A6 HPBgS, A7 - PBgS, A8 - HPBgS, A9 - HPBgS; Polar Circle SNCR: B1 -PBPS, B2 - HPBgS, B3 - HPBgS. II. The northeastern sub-region of the Atlantic-Arctic forest region of the temperate zone. Komi Republic. Pechora-llych SNBR: C1 - RPBS, C2 - RPBS, C3 - IFgP, C4 - IFgP, C5 - TPBS, C6 - PBPS, C7 - PBPS. See a more detail description of the studied sites in "Methods: Studied area description" 


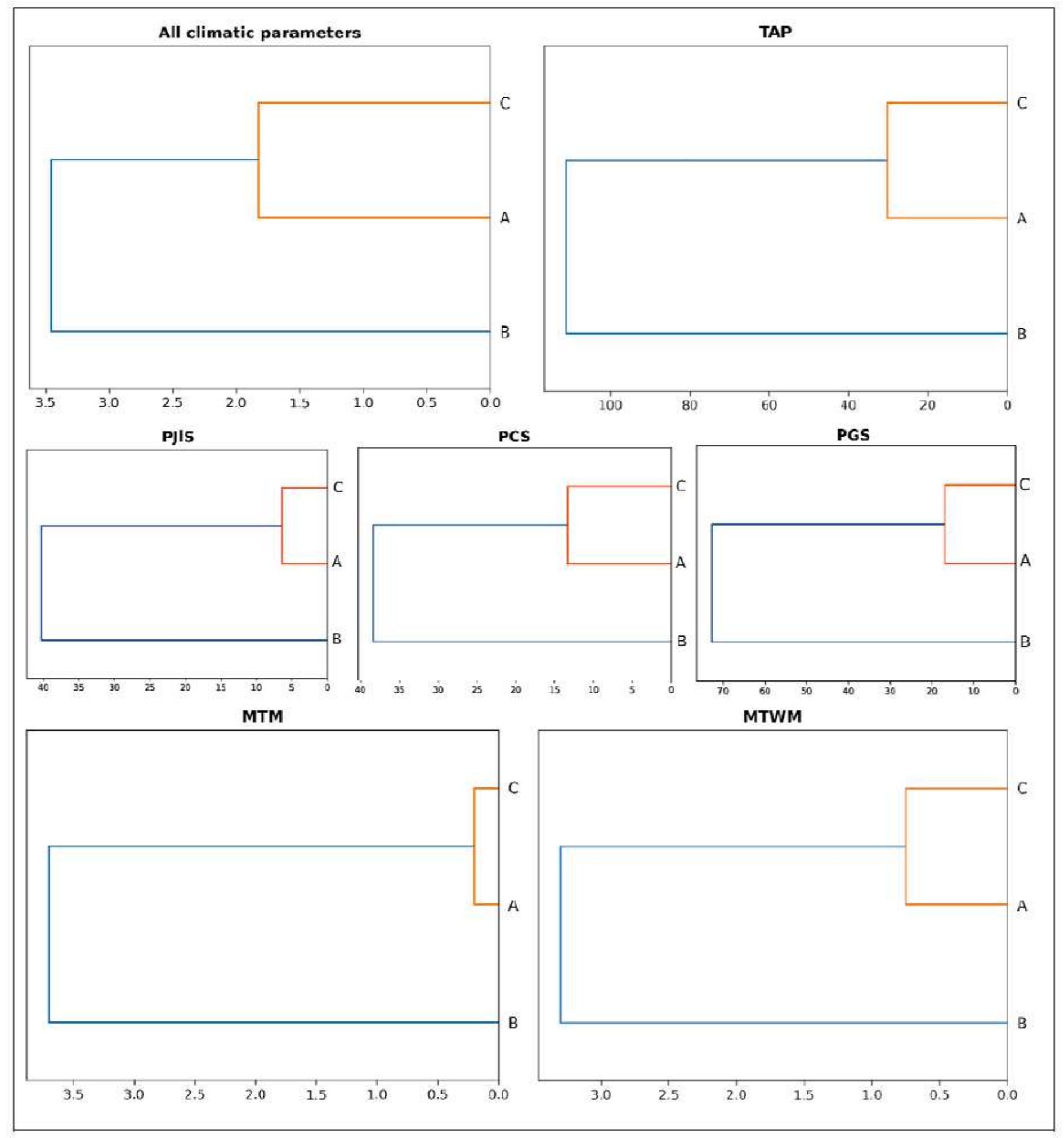

\section{Figure 4}

Cluster analysis of the values of climatic parameters of the three SPNTs studied, averaged for the period 1991-2010 (All climatic parameters; TAP - total annual precipitation, mm; PJIS - precipitation in JulySeptember, $\mathrm{mm}$; PCS - precipitation in cold season, $\mathrm{mm}$; PGS - precipitation in the growing season, $\mathrm{mm}$; MTM - mean temperature in May, ${ }^{\circ} \mathrm{C}$; MTWM - mean temperature in the warmest month (July), $\left.{ }^{\circ} \mathrm{C}\right)$. 
Studying sites: A - Kivach SNR, B - Polar Circle SNCR, C - Pechora-llych SNBR. The abscissa indicates the Euclidean distance

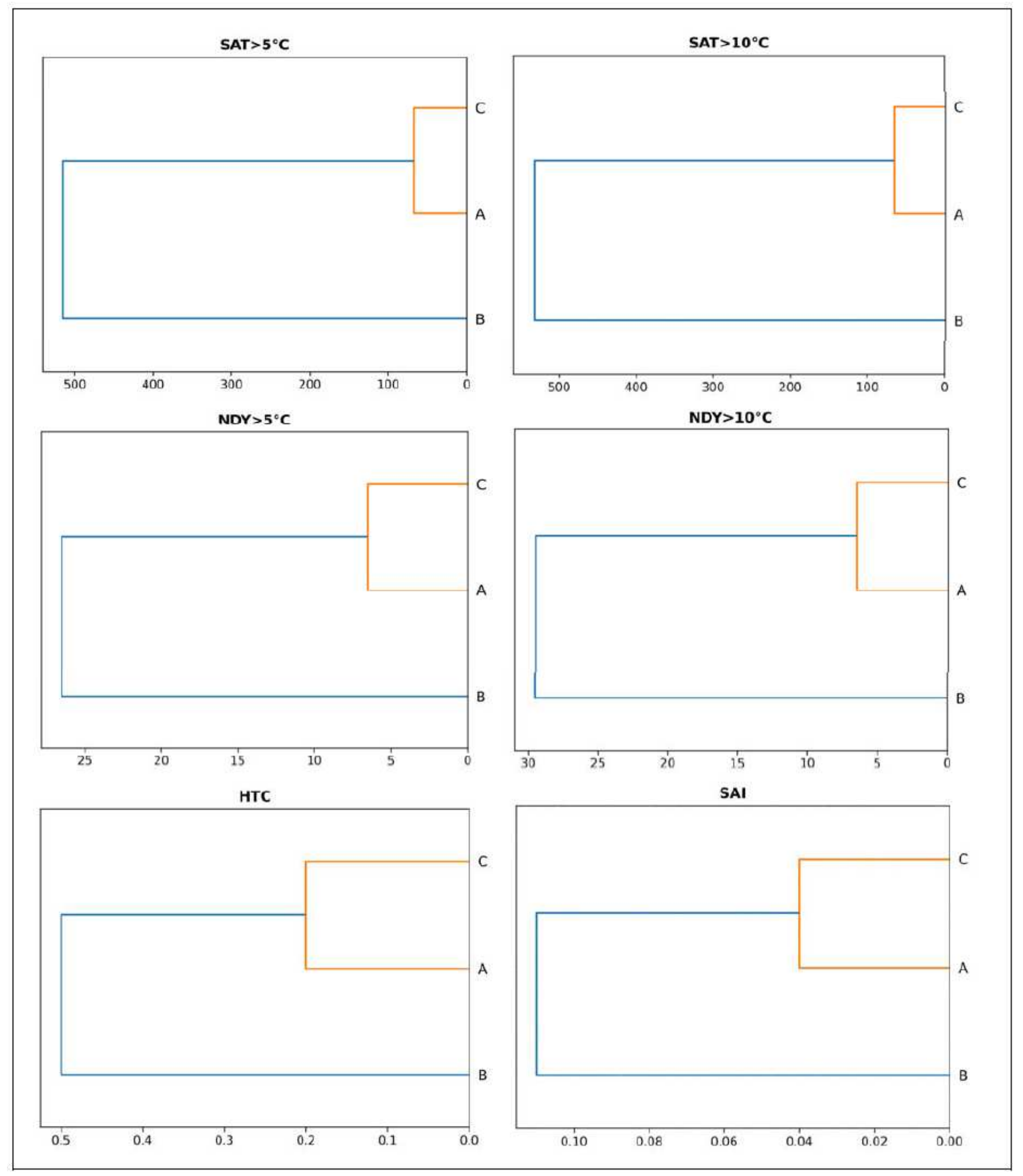

Figure 5

Cluster analysis of the values of climatic parameters of the three SPNTs studied, averaged for the period 1991-2010 (SAT $>5^{\circ} \mathrm{C}$ - Sum of active temperature above $5^{\circ} \mathrm{C},{ }^{\circ} \mathrm{C} \times$ days; SAT $>10^{\circ} \mathrm{C}$ - Sum of active temperature above $10^{\circ} \mathrm{C},{ }^{\circ} \mathrm{C} \times$ days; $N D Y>5^{\circ} \mathrm{C}$ - the number of days in a year with temperatures above $5^{\circ} \mathrm{C}$, 
days; NDY $>10^{\circ} \mathrm{C}$ - the number of days in a year with temperatures above $10^{\circ} \mathrm{C}$, days; $\mathrm{HTC}$ - Selyaninov's Hydrothermal coefficient; SAI - Simplified aridity index). Studying sites: A - Kivach SNR, B - Polar Circle SNCR, C - Pechora-llych SNBR. The abscissa indicates the Euclidean distance

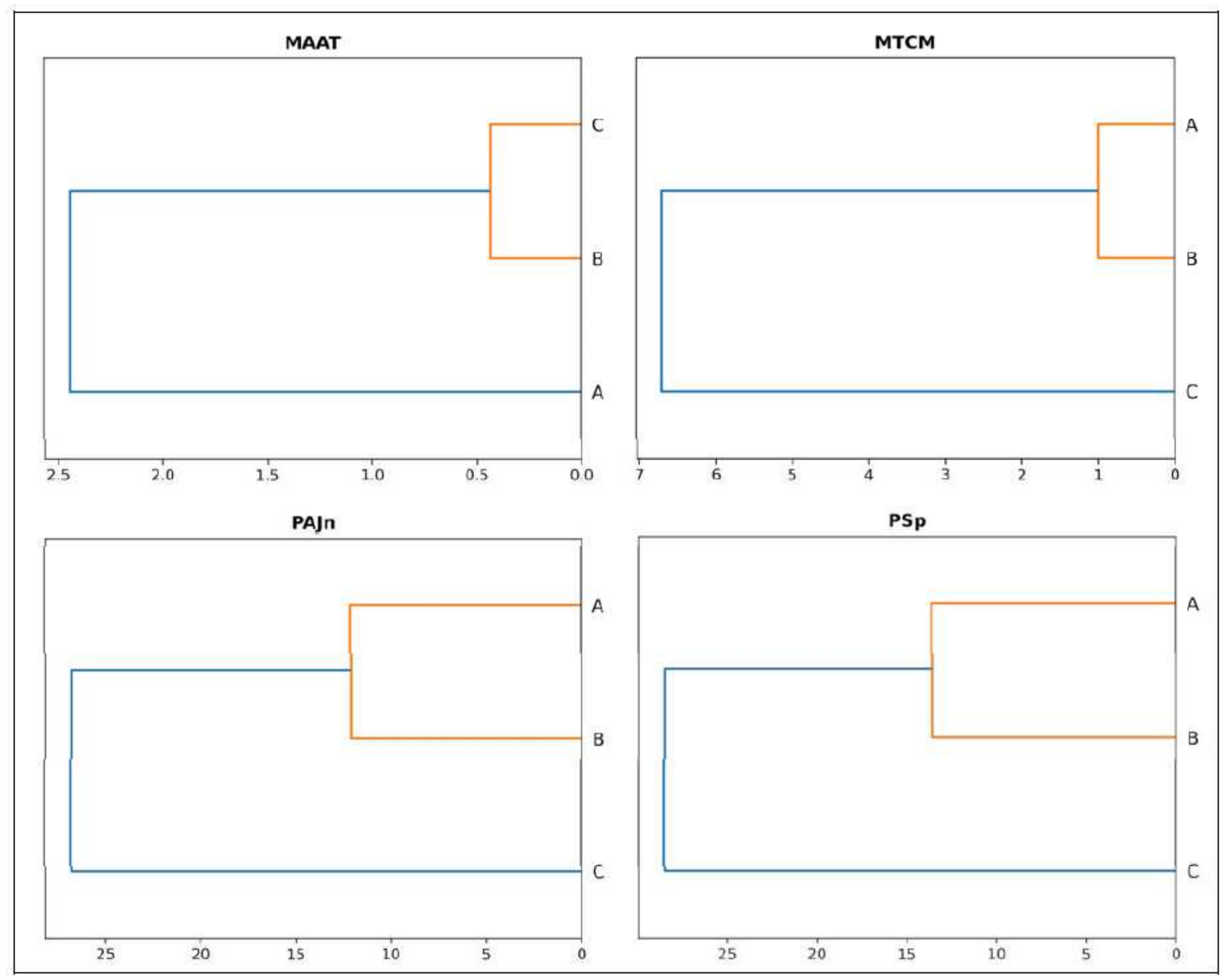

Figure 6

Cluster analysis of the values of climatic parameters of the three SPNTs studied, averaged for the period 1991-2010 (MAAT - mean annual air temperature, ${ }^{\circ} \mathrm{C}$; MTCM - mean temperature in the coldest month (January), ${ }^{\circ} \mathrm{C}$; PSp - precipitation in spring, mm; PAJn - precipitation in April-June, mm). Studying sites: A Kivach SNR, B - Polar Circle SNCR, C - Pechora-llych SNBR. The abscissa indicates the Euclidean distance 